\title{
Record Longevities of Vegetable Seeds in Storage
}

\author{
E.E. Roos ${ }^{1}$ and D.A. Davidson ${ }^{2}$ \\ U.S. Department of Agriculture, Agricultural Research Service, National Seed Storage Laboratory, \\ Fort Collins, CO 80523
}

\begin{abstract}
Agricultural production of food and fiber depends on the ability of seeds to dry and become quiescent for a period before planting for the next season's crop. In many instances seed must be kept for more than one season; plant breeders may hold seed lots for several years before their use, while gene banks may store seed for decades before distribution. For this reason, seed longevity has been of interest to scientists and laypersons
\end{abstract} alike.

Recent reviews by Ellis (1991), Priestley (1986), Roos (1986), and Toole (1986) have examined the topic of seed longevity. Reports of 'Mummy' wheat seeds surviving 3000 years in Egyptian pyramids are clearly specious (Justice and Bass, 1978; Roos, 1986). Evidence from other archeological sites (Lerman and Cigliano, 1971; Odum, 1965; Sivori et al., 1968), museum herbaria (Becquerel, 1934; Ewart, 1908; Nature, 1942; Youngman, 1951), and buried seed experiments (Kivilaan and Bandurski, 1981) support the thesis that seeds of many species are capable of surviving for more than a century.

Most of the reports of extreme seed longevity have centered on agronomic and weed seeds; while many vegetable seeds are reported to be relatively short lived (Barton, 1961; Boswell et al., 1940; Justice and Bass, 1978; Priestley et al., 1985). Reports of viable vegetable seeds occurring in prehistoric caches in the southwestern United States have appeared in the popular press; however, as pointed out by Nabhan (1977), "The data are unfortunately inadequate to establish with any confidence that Southwestern crop seed from well-defined prehistoric cultural deposits have indeed germinated upon their recent recovery."

Bass (1981) reported that documented evidence for vegetable seed longevity seldom exceeded 30 years. Barton (1953) stored seed of carrot (Daucus carota L.), eggplant (Solanum melongena L.), lettuce (Lactuca sativa L.), onion (Allium cepa L.), pepper (Capsicum annuum L.), and tomato (Lycopersicon esculentum L.) at ambient temper-

Received for publication 30 Aug. 1991. Accepted for publication 2 Jan. 1992. The assistance of Karen Utterback in assembling old germination records and Sudhir Nath for statistical analyses is gratefully acknowledged. The cost of publishing this paper was defrayed in part by the payment of page charges. Under postal regulations, this paper therefore must be hereby marked advertisement solely to indicate this fact.

'Supervisory Plant Physiologist, to whom correspondence should be addressed.

${ }^{2}$ Biological Technician. ature in the laboratory and at $-4 \mathrm{C}$. Only seeds of carrot, eggplant, and tomato, stored at ambient temperature, were still viable after 20 years, while seeds of all species stored at $-4 \mathrm{C}$ were still viable. For example, seeds of onion germinated $93 \%$ when stored dry and sealed at $-4 \mathrm{C}$. Unfortunately, these experiments were not continued.

Documented seed longevities for 15 veg-

etable species are presented in Table 1. James et al. (1964), who reported on the longevity of several vegetable seed lots stored 15 to 30 years at Cheyenne, Wyo., are the source of many of these data. Many of these seed lots are still viable and are the subject of this paper. Interim germination data on some of these seed lots have been presented by Roos (1989).

Table 1. Previously documented longevities of vegetable seeds.

\begin{tabular}{|c|c|c|c|}
\hline Species and cultivar & $\begin{array}{c}\text { Age } \\
\text { (years) }\end{array}$ & $\begin{array}{l}\text { Germination } \\
(\%)\end{array}$ & Reference \\
\hline \multicolumn{4}{|l|}{ Bean (Phaseolus vulgaris L.) } \\
\hline Unknown & 18 & 99 & Bass, 1981 \\
\hline Alberta Brown & 29 & 26 & James et al., 1964 \\
\hline \multicolumn{4}{|l|}{ Beet (Beta vulgaris L.) } \\
\hline Unknown (sugar beet) & 22 & 75 & Pack and Owen, 1950 \\
\hline Extra Early Bassano & 31 & 31 & James et al., 1964 \\
\hline \multicolumn{4}{|l|}{ Carrot (Daucus carota L.) } \\
\hline Unknown & 20 & 63 & Barton, 1953 \\
\hline Int. Yellow Stump Rooted & 31 & 5 & James et al., 1964 \\
\hline \multicolumn{4}{|l|}{ Corn (Zea mays L.) } \\
\hline Early Surprise & 23 & 82 & James et al., 1964 \\
\hline Dakota Flint & 32 & 79 & Haferkamp et al., 1953 \\
\hline \multicolumn{4}{|l|}{ Cucumber (Cucumis sativus L.) } \\
\hline Unknown & 17 & 98 & Bass, 1981 \\
\hline Butcher's & 30 & 77 & James et al., 1964 \\
\hline \multicolumn{4}{|l|}{ Eggplant (Solanum melongena L.) } \\
\hline Unknown & 20 & 86 & Barton, 1953 \\
\hline Black Pekin & 30 & 30 & James et al., 1964 \\
\hline \multicolumn{4}{|l|}{ Muskmclon (Cucumis melo L.) } \\
\hline Delicious 51 & 23.5 & 81 & Bass, 1983 \\
\hline West's & 30 & 96 & James et al., 1964 \\
\hline \multicolumn{4}{|l|}{ Okra [Abelmoschus esculentus (L.) } \\
\hline \multicolumn{4}{|l|}{ Moench] } \\
\hline Unknown & 17 & 92 & Bass, 1981 \\
\hline Extra Early Dwarf Green Pod & 22 & 60 & James et al., 1964 \\
\hline \multicolumn{4}{|l|}{ Onion (Allium cepa L.) } \\
\hline Brigham Yellow Globe & 22 & 75 & Newhall and Hoff, 1960 \\
\hline Southport White Globe & 27 & 15 & James et al., 1964 \\
\hline \multicolumn{4}{|l|}{ Pea (Pisum sativum L.) } \\
\hline Alaska & 24 & 86 & James et al., 1964 \\
\hline Solo & 31 & 78 & Haferkamp et al., 1953 \\
\hline \multicolumn{4}{|l|}{ Pepper (Capsicum annuum L.) } \\
\hline Unknown & 20 & 19 & Barton, 1953 \\
\hline World Beater & 29 & 34 & James et al., 1964 \\
\hline \multicolumn{4}{|l|}{ Spinach (Spinacia oleracea L.) } \\
\hline Marco & 30 & 8 & James et al., 1964 \\
\hline Unknown & 61 & 1 & Buchwald and Jensen, 1974 \\
\hline \multicolumn{4}{|l|}{$\begin{array}{l}\text { Swiss chard (Beta vulgaris L. var. } \\
\text { Cicla) }\end{array}$} \\
\hline Unknown & 15 & 94 & Bass, 1981 \\
\hline Burpee's Rhubarb & 20 & 88 & James et al., 1964 \\
\hline \multicolumn{4}{|l|}{ Tomato (Lycopersicon esculentum } \\
\hline \multicolumn{4}{|l|}{ Mill.) } \\
\hline Marmon & 32 & 87 & James et al., 1964 \\
\hline Unknown & 43 & 76 & Bass, 1981 \\
\hline \multicolumn{4}{|l|}{$\begin{array}{l}\text { Watermelon [Citrullus lanatus } \\
\text { Thunb. (Matsum. \& Makai)] }\end{array}$} \\
\hline Thunb. (Matsum. \& Makai)] & & & \\
\hline Unknown & 17 & 94 & Bass, 1981 \\
\hline Arikara & 30 & 92 & James et al., 1964 \\
\hline
\end{tabular}


The objectives of this study were to extend the data base on known vegetable seed longevities and compare longevities among species.

\section{BACKGROUND}

In $1962, \approx 2000$ vegetable seed lots were transferred to the National Seed Storage Laboratory (NSSL). These lots had been stored in metal drawers in an office at the U.S. Dept. of Agriculture Horticultural Field Station in Cheyenne. Old seed lots from 15 vegetable species, represented by three to six cultivars (Table 2), were selected for study. These lots, although not specifically identified, were included in a previous report by James et al. (1964). All seedlots have been in storage at the NSSL in Fort Collins, Colo., since their acquisition in 1962. At the time of acquisition, some of the lots were included in the base collection of the NSSL and thus were stored at low temperature and low seed moisture. From 1962 until $\approx 1977$ the storage conditions were $5 \mathrm{C}$ and $<40 \%$ relative humidity (RH); after 1977 seeds were stored in sealed moisture-proof bags at $-18 \mathrm{C}$ (see Roos, 1989, for additional description of storage conditions at NSSL). Other lots were held in paper envelopes in metal trays at room temperature (20C) and ambient $\mathrm{RH}$ $(\leq 50 \%)$ for several years (exact time period unknown) before being placed in low-temperature storage (either 5 or - 18C).

Remnant seeds from the experiment conducted by James et al. (1964) were reexamined for viability in 1991 under standard germination conditions (Assn. Official Seed Analysts, 1988). Due to the limited quantities of seed available, 25, 50, or 100 seeds were tested, and for a few samples, only 10 seeds were tested. Between 1962 and 1991, all of these lots were retested at irregular intervals, thus providing sequential observations (four to 11) of germination percentage for each seed lot. The oldest tests (on a few samples) were done in 1946 and reported to M.F. Babb at the Cheyenne Horticultural Field Station in a letter from E.H. Toole (U.S. Dept. Agriculture, Beltsville, Md.) dated 28 June 1946. No data are available on the initial germination values when the seeds were originally acquired or produced in Cheyenne.

Seed germination data were examined for each lot, and the half or median viability periods $\left(\mathrm{P}_{50}\right)$ (Roberts, 1972) were calculated as described by Moore and Roos (1982) and Moore et al. (1983). No adjustment was made for initial mortality. In determining the significance of the $\chi^{2}$ and regression statistics (Table 2) the degree of freedom for each seed lot was two less than the number of germination tests performed.

\section{FINDINGS}

The oldest seed lot tested was a tomato cultivar, Marmon, that still germinated $82 \%$ after 60 years in storage (Table 2). Longevities of $\geq 50$ years are reported for beet (Beta
Table 2. Germination and estimates of longevity statistics of vegetable seeds following long-term storage.

\begin{tabular}{|c|c|c|c|c|c|c|c|}
\hline \multirow[b]{2}{*}{ Species and cultivar } & \multirow{2}{*}{$\begin{array}{c}\text { Age }^{\mathbf{z}} \\
\text { (years) }\end{array}$} & \multicolumn{2}{|c|}{$\begin{array}{c}\text { Germination } \\
(\%)\end{array}$} & \multirow{2}{*}{$\begin{array}{c}\mathrm{P}_{50} \pm \mathrm{SE} \\
\text { (years) }\end{array}$} & \multirow[b]{2}{*}{ df } & \multirow[b]{2}{*}{$x^{2}$} & \multirow[b]{2}{*}{$r$} \\
\hline & & $1963^{y}$ & $1991^{x}$ & & & & \\
\hline \multicolumn{8}{|l|}{ Bean (Phaseolus vulgaris) } \\
\hline Wyoming Pinto & 48 & 72 & $24^{w}$ & $31 \pm 1$ & 7 & $5^{\mathrm{NS}}$ & $0.95^{* *}$ \\
\hline Idaho Pinto & 47 & 70 & $8^{w}$ & $20 \pm 1$ & 7 & $35^{* *}$ & $0.85^{* *}$ \\
\hline Dwarf Green Pod & 46 & 64 & $64^{\mathrm{w}}$ & $90 \pm 48$ & 6 & $12^{\mathrm{NS}}$ & $0.11^{\mathrm{NS}}$ \\
\hline Vermont Cranberry & 45 & 78 & 52 & $51 \pm 4$ & 5 & $18^{* *}$ & $0.76^{*}$ \\
\hline Hidatsa & 45 & 78 & $30^{\mathrm{v}}$ & $37 \pm 2$ & 6 & $47^{* *}$ & $0.71^{*}$ \\
\hline Avg & & 72 & 36 & 46 & & & \\
\hline \multicolumn{8}{|l|}{ Beet (Beta vulgaris) } \\
\hline Extra Early Bassano & 59 & 71 & $8^{\mathrm{y}}$ & $39 \pm 1$ & 7 & $37^{* *}$ & $0.89^{* *}$ \\
\hline Long Smooth Blood Tumip & 56 & 62 & 18 & $41 \pm 1$ & 6 & $34^{* *}$ & $0.87^{* *}$ \\
\hline Earlidark & 53 & 63 & 14 & $35 \pm 1$ & 7 & $51^{* *}$ & $0.80^{* *}$ \\
\hline Extra Early Red Turnip & 49 & 85 & 36 & $43 \pm 1$ & 4 & $3^{\mathrm{NS}}$ & $0.99 * *$ \\
\hline Green Top Bunching & 48 & 64 & 28 & $34 \pm 1$ & 6 & $59^{* *}$ & $0.75^{*}$ \\
\hline Early Flat Egyptian & 47 & 94 & 78 & $66 \pm 6$ & 4 & $14^{* *}$ & $0.80^{\mathrm{NS}}$ \\
\hline Avg & & 73 & 30 & 43 & & & \\
\hline Carrot (Daucus carota) & & & & & & & \\
\hline Nantes Touchon Strain & 46 & 63 & 24 & $30 \pm 1$ & 8 & $12^{\mathrm{NS}}$ & $0.86^{* *}$ \\
\hline Selected Long Orange Improved & 46 & 70 & 22 & $30 \pm 1$ & 8 & $10^{\mathrm{NS}}$ & $0.90^{* *}$ \\
\hline Nancy & 45 & 61 & 26 & $28 \pm 2$ & 6 & $25^{* *}$ & $0.67^{\mathrm{NS}}$ \\
\hline New Early Coreless & 43 & 76 & 72 & $68 \pm 16$ & 6 & $24^{* *}$ & $0.45^{\mathrm{NS}}$ \\
\hline Wonderkugel & 43 & 61 & 14 & $19 \pm 1$ & 7 & $12^{\mathrm{NS}}$ & $0.89^{* *}$ \\
\hline Avg & & 66 & 32 & 35 & & & \\
\hline Corn (Zea mays) & & & & & & & \\
\hline Early Surprise & 50 & 82 & 56 & $52 \pm 3$ & 6 & $12^{\mathrm{NS}}$ & $0.85^{* *}$ \\
\hline Marcross Northern & 48 & 94 & 64 & $61 \pm 5$ & 4 & $4^{\text {NS }}$ & $0.94^{* *}$ \\
\hline Lee (Resistant) & 47 & 90 & 72 & $65 \pm 8$ & 4 & $5^{\mathrm{NS}}$ & $0.87^{*}$ \\
\hline Earligold & 46 & 92 & 84 & $86 \pm 17$ & 4 & $20^{* *}$ & $0.58^{\mathrm{NS}}$ \\
\hline Golden No. 10 & 45 & 90 & 70 & $63 \pm 8$ & 4 & $16^{* *}$ & $0.72^{\mathrm{NS}}$ \\
\hline Avg & & 90 & 69 & $\overline{65}$ & & & \\
\hline Cucumber (Cucumis sativus) & & & & & & & \\
\hline Danish Common & 58 & 69 & $28^{w}$ & $39 \pm 1$ & 4 & $27^{* *}$ & $0.76^{\mathrm{NS}}$ \\
\hline Snake & 58 & 70 & 28 & $32 \pm 2$ & 4 & $20^{* *}$ & $0.73^{\mathrm{NS}}$ \\
\hline Lange Kecskemeter & 54 & 79 & 48 & $52 \pm 4$ & 6 & $16^{*}$ & $0.73^{*}$ \\
\hline Marketer & 46 & 73 & 62 & $48 \pm 10$ & 8 & $97^{* *}$ & $0.19^{\mathrm{NS}}$ \\
\hline National Pickling & 45 & 87 & 62 & $53 \pm 6$ & 5 & $10^{\mathrm{NS}}$ & $0.77^{*}$ \\
\hline Avg & & 76 & 46 & $\overline{45}$ & & & \\
\hline Eggplant (Solanum melongena) & & & & & & & \\
\hline Ebony King & 56 & 69 & 4 & $33 \pm 1$ & 6 & $32 * *$ & $0.90 * *$ \\
\hline Fort Myers Market & 55 & 67 & 44 & $39 \pm 2$ & 8 & $24^{* *}$ & $0.83^{* *}$ \\
\hline Blackee & 50 & 62 & 12 & $27 \pm 1$ & 5 & $6^{\mathrm{NS}}$ & $0.95^{* *}$ \\
\hline Minnoval & 48 & 92 & 80 & $119 \pm 51$ & 2 & $5^{\mathrm{NS}}$ & $0.61^{\text {NS }}$ \\
\hline Avg & & 72 & 35 & 54 & & & \\
\hline Muskmelon (Cucumis melo) & & & & & & & \\
\hline Extra Early Sunrise & 58 & 82 & 42 & $53 \pm 2$ & 6 & $7^{\mathrm{NS}}$ & $0.94^{* *}$ \\
\hline Perfection & 56 & 75 & 28 & $47 \pm 1$ & 5 & $43^{* *}$ & $0.77^{*}$ \\
\hline Bush Jenny Lind & 55 & 79 & 52 & $55 \pm 3$ & 7 & $54^{* *}$ & $0.66^{\mathrm{NS}}$ \\
\hline New Ideal & 53 & 99 & 76 & $70 \pm 5$ & 4 & $4^{\mathrm{NS}}$ & $0.93^{* *}$ \\
\hline Early Sunrise & 50 & $92^{\circ}$ & 74 & $79 \pm 14$ & 4 & $18^{* *}$ & $0.60^{\mathrm{NS}}$ \\
\hline Avg & & 85 & 54 & $\overline{61}$ & & & \\
\hline Okra (Abelmoschus esculentus) & & & & & & & \\
\hline Extra Early Dwarf Green Pod & 50 & $60^{x}$ & 34 & $24 \pm 3$ & 4 & $28^{* *}$ & $0.64^{\mathrm{NS}}$ \\
\hline Wyoming No. 9 & 48 & $99^{x}$ & 62 & $53 \pm 2$ & 3 & $6^{\mathrm{NS}}$ & $0.95^{* *}$ \\
\hline Wyoming No. 10 & 47 & $84^{x}$ & 72 & $130 \pm 71$ & 6 & $14^{*}$ & $0.35^{\mathrm{NS}}$ \\
\hline Wyoming No. 5 & 45 & $96^{x}$ & $90^{\circ}$ & $161 \pm 102$ & 3 & $24^{* *}$ & $0.25^{\mathrm{NS}}$ \\
\hline Wyoming No. 4 & 45 & $82^{x}$ & $70^{v}$ & $258 \pm 573$ & 4 & $31^{* *}$ & $0.07^{\mathrm{NS}}$ \\
\hline Avg & & 84 & 66 & 125 & & & \\
\hline Onion (Allium cepa) & & & & & & & \\
\hline Valencia Sweet Spanish & 52 & 76 & $20^{\mathrm{v}}$ & $33 \pm 1$ & 5 & $34 * *$ & $0.88^{* *}$ \\
\hline Early Yellow Sweet Spanish & 49 & 66 & 32 & $32 \pm 1$ & 9 & $51^{* *}$ & $0.80^{* *}$ \\
\hline Yellow Sweet Spanish & 48 & 79 & 14 & $32 \pm 1$ & 8 & $25^{* *}$ & $0.88^{* *}$ \\
\hline San Joaquin & 47 & 94 & 20 & $38 \pm 1$ & 4 & $61^{* *}$ & $0.87^{*}$ \\
\hline Espanola & 46 & 61 & 38 & $11 \pm 6$ & 8 & $47^{* *}$ & $0.45^{\mathrm{NS}}$ \\
\hline Avg & & 75 & 25 & 29 & & & \\
\hline Pea (Pisum sativum) & & & & & & & \\
\hline Alaska & 51 & $86^{x}$ & 94 & $--^{t}$ & 4 & $14^{* *}$ & $0.56^{\mathrm{NS}}$ \\
\hline Buxbom I & 51 & $76^{x}$ & 82 &..$- t^{t}$ & 5 & $8^{\mathrm{NS}}$ & $0.36^{\mathrm{NS}}$ \\
\hline Randolph Indian Var.13, St.D & 51 & $64^{x}$ & 56 & $\ldots-{ }^{t}$ & 6 & $27^{* *}$ & $0.03^{\mathrm{NS}}$ \\
\hline Radio & 51 & $76^{x}$ & $45^{y}$ & $46 \pm 3$ & 4 & $16^{* *}$ & $0.77^{\mathrm{NS}}$ \\
\hline Pedigree Extra Early & 48 & $90^{x}$ & 82 & $232 \pm 292$ & 5 & $14^{*}$ & $0.18^{\mathrm{Ns}}$ \\
\hline $\begin{array}{l}\text { Extra Early D.S.C. } \\
\text { Avg }\end{array}$ & 45 & $\begin{array}{c}100^{x} \\
82\end{array}$ & $\begin{array}{l}92 \\
75\end{array}$ & $111_{130} 42$ & 3 & $1^{\mathrm{NS}}$ & $0.86^{\mathrm{NS}}$ \\
\hline
\end{tabular}




\begin{tabular}{|c|c|c|c|c|c|c|c|}
\hline \multirow[b]{2}{*}{ Species and cultivar } & \multirow{2}{*}{$\begin{array}{c}\text { Age }^{z} \\
\text { (years) }\end{array}$} & \multicolumn{2}{|c|}{$\begin{array}{c}\text { Germination } \\
(\%)\end{array}$} & \multirow{2}{*}{$\begin{array}{c}P_{50} \pm S E \\
\text { (years) }\end{array}$} & \multirow[b]{2}{*}{ df } & \multirow[b]{2}{*}{$\chi^{2}$} & \multirow[b]{2}{*}{$r$} \\
\hline & & $1963^{y}$ & $1991^{x}$ & & & & \\
\hline Sweet (Thomsen's Own Select.) & 51 & 84 & 28 & $37 \pm 2$ & 3 & $49 * *$ & $0.68^{\mathrm{NS}}$ \\
\hline Early Market & 49 & .70 & 2 & $28 \pm 1$ & 6 & $17^{*}$ & $0.92^{* *}$ \\
\hline Victory & 45 & 76 & 10 & $26 \pm 1$ & 3 & $27^{* *}$ & $0.86^{\mathrm{NS}}$ \\
\hline World Beater No. 13 & 45 & 66 & 26 & $17 \pm 3$ & 4 & $58^{* *}$ & $0.54^{\mathrm{NS}}$ \\
\hline Avg & & 74 & 16 & 27 & & & \\
\hline \multicolumn{8}{|l|}{ Spinach (Spinacia oleracea) } \\
\hline Blight Resistant Savoy & 45 & 67 & $60^{v}$ & $43 \pm 8$ & 7 & $29 * *$ & $0.35^{\mathrm{NS}}$ \\
\hline Mt. Evergreen & 45 & 66 & 14 & $30 \pm 1$ & 7 & $121^{* *}$ & $0.57^{\mathrm{NS}}$ \\
\hline Viking & 43 & 83 & 40 & $38 \pm 1$ & 4 & $63^{* *}$ & $0.76^{\mathrm{NS}}$ \\
\hline Avg & & 72 & 38 & 37 & & & \\
\hline \multicolumn{8}{|l|}{ Swiss chard (Beta vulgaris var. Cicla) } \\
\hline Burpee's Rhubard & 48 & $88^{x}$ & 70 & $68 \pm 8$ & 4 & $24 * *$ & $0.65^{\mathrm{NS}}$ \\
\hline Special Large White Ribbed & 47 & $76^{x}$ & 66 & $64 \pm 11$ & 5 & $18^{* *}$ & $0.58^{\mathrm{NS}}$ \\
\hline Fordhook Giant & 45 & $74^{x}$ & 70 & $65 \pm 9$ & 4 & $25^{* *}$ & $0.60^{\mathrm{NS}}$ \\
\hline Dark Green & 45 & $88^{x}$ & 60 & $36 \pm 1$ & 4 & $70^{* *}$ & $0.84^{*}$ \\
\hline Avg & & 82 & 66 & 58 & & & \\
\hline \multicolumn{8}{|l|}{ Tomato (Lycopersicon esculentum) } \\
\hline Marmon & 60 & 87 & 82 & $230 \pm 233$ & 3 & $4^{\mathrm{NS}}$ & $0.38^{\mathrm{NS}}$ \\
\hline Early Bird & 59 & 96 & 40 & $56 \pm 1$ & 4 & $35^{* *}$ & $0.87^{*}$ \\
\hline Florida Special & 58 & 92 & 76 & $103 \pm 23$ & 3 & $6^{\mathrm{NS}}$ & $0.73^{\mathrm{NS}}$ \\
\hline Morse's Special Early & 57 & 95 & 82 & $109 \pm 25$ & 3 & $6^{\mathrm{NS}}$ & $0.75^{\mathrm{NS}}$ \\
\hline Beauty of Loraine & 56 & 95 & 98 &.--1 & 3 & $32 * *$ & $0.08^{\mathrm{NS}}$ \\
\hline Avg & & 93 & 76 & 124 & & & \\
\hline \multicolumn{8}{|l|}{ Watermelon (Citrullus lanatus) } \\
\hline Colorado Preserving Citron & 58 & 82 & $32^{w}$ & $41 \pm 1$ & 5 & $62 * *$ & $0.70^{\mathrm{NS}}$ \\
\hline Arikara & 57 & 76 & 20 & $34 \pm 1$ & 5 & $26 * *$ & $0.79^{*}$ \\
\hline Will's Sugar (28140.01) & 57 & 88 & 24 & $47 \pm 1$ & 4 & $12^{* *}$ & $0.95^{* *}$ \\
\hline New Winter & 56 & 92 & 34 & $46 \pm 1$ & 5 & $65^{* *}$ & $0.77^{*}$ \\
\hline Will's Sugar (28142.01) & 55 & 76 & $52^{w}$ & $48 \pm 2$ & 4 & $44^{* *}$ & $0.74^{\mathrm{NS}}$ \\
\hline Avg & & 83 & 32 & 43 & & & \\
\hline
\end{tabular}

${ }^{2}$ Calculated from year seed was purchased to 1991 .

y $\mathrm{Gcrmination}$ test of 100 seeds unless noted.

${ }^{x}$ Germination test of 50 seeds unless noted.

wermination test of 25 seeds.

${ }^{\vee}$ Germination test of 10 seeds.

"Germination tested in 1967.

'Negative $P_{50}$

Ns,*,**Nonsignificant or significant at $P=0.05$ or 0.01 , respectively.

vulgaris L.), corn (Zea mays L.), cucumber (Cucumis sativus L.), eggplant, muskmelon (Cucumis melo L.), okra [Abelmoschus esculentum L. (Moench.)] , onion, pea (Pisum sutivum L.), pepper, and watermelon [Citrullus lanatus Thunb. (Matsum. \& Makai)]. Surprisingly, carrot, onion, and pepper seeds, usually thought to have relatively short viability periods, germinated $72 \%$ ('New Early Coreless'), 28\% ('Sweet, Thomsen's Own Select'), and 38\% ('Espanola') after 43, 46, and 51 years, respectively.

With only a few exceptions, germination declined significantly from 1963 to 1991 . On average, most species lost $\geq 30 \%$ viability, except for corn, okra, pea, Swiss chard (Beta vulgaris var. Cicla L.), and tomato (Table 2). Species showing the greatest loss in viability were onion, pepper, and watermelon, which lost, on average, $50 \%, 58 \%$, and $51 \%$ germination, respectively, after 29 years. Pea seeds, in contrast, lost an average of only 7\% germination between 1963 and 1991.

Although the data varied considerably from cultivar to cultivar, even within a species, four groups can be identified for $\mathrm{P}_{50}$ (Table 2). Species with a $P_{50}$ of $>100$ years would include okra, pea, and tomato; species in the 50- to 70-year range would include corn, eggplant, muskmelon, and Swiss chard; species in the 30- to 50-year range would in- clude bean, beet, carrot, cucumber, spinach (Spinacia oleracea L.), and watermelon; while those in the <30-year range would be onion and pepper.

\section{Implications}

Seed moisture content and storage temperature are well known to be the principal factors in determining seed longevity (Justice and Bass, 1978). However, in this experiment, neither of these factors was precisely known throughout the 60-year storage duration. As discussed by James et al. (1964), the original storage conditions in Cheyenne were cool and dry and most likely resulted in the seeds achieving a low equilibrium moisture content. Storage conditions at NSSL also would have promoted low seed moisture content. Recent studies have shown that equilibrating seeds against $\mathrm{RH}$ of $\approx 25 \%$ or lower greatly extends seed longevity, even at ambient temperatures (Ellis et al., 1989, 1990a, 1990b; Vertucci and Roos, 1990). Presumably, the storage conditions for the seeds tested certainly would have contributed to the extreme longevities reported.

Genetic and physiological factors important in seed longevity include the species, seed lot, and/or cultivar, and the original seed quality. These factors are taken into account as constants in the seed viability equation proposed by Roberts (1973) and Ellis and Roberts (1980). Here, cultivars are known from the names written on the original seed packets; however, no data are available on the initial seed viability or quality (vigor). Presumably, the lots used in this study were of high quality and vigor, as most of the other seed lot transferred from Cheyenne either died or were of lower viability after long-term storage. Thus, extreme caution must be taken in interpreting these results, as storage conditions were not constant for all species and seed lots tested, and only data for the best-storing seed lots are presented. However, the data do establish new upper limits to the longevity of all species tested.

The data presented provided a unique opportunity to apply a computer probit analysis program, developed to compute statistics for the evaluation of $\mathrm{P}_{50}$ (Moore and Roos, 1982; Moore et al., 1983), to the analysis of vegetable seed deterioration data accumulated under slow-aging conditions, as would be encountered in germplasm banks. Priestley et al. (1985) used this probit analysis program to compare differences in seed longevity at the species level; however, the data used by them were very heterogeneous, being taken from diverse cultivars and storage locations. Of the vegetable species included in their analysis, none had a $\mathrm{P}_{50}$ of $>25$ years, including tomato, which was just $<25$ years.

There are three important statistics generated to test the validity of this approach to analyzing longevities, including the SE of the $\mathrm{P}_{50}$; an estimate of the normality of the distribution $\left(\chi^{2}\right)$ of seed deaths in time (an assumption for applying the probit transformation); and a goodness of fit $\left(r^{2}\right)$ for the regression of probit germination on storage time. The data (Table 2 ) reveal numerous cases where either a significant $\chi^{2}$ (nonnormal distribution) or a nonsignificant correlation coefficient (lack of relationship between germination and storage time) is encountered. Usually, these data sets are accompanied by large SE of the $\mathrm{P}_{50}$, indicative of low confidence in the value determined (exceptions being when little or no deterioration occurred). Explanations for these poor values are numerous and include one or more of the following: a) nonuniform storage conditions (temperature and $\mathrm{RH}$ ); b) extreme variability in the germination data, caused by poor sampling and/or the small number of seeds tested; c) variations in seed testing conditions and interpretation; d) lack of seed deterioration; and e) too few data points. In spite of all of these factors, useful information has been generated to evaluate storage longevity at the species level.

The generally accepted belief that some vegetable species (notably carrot, onion, and pepper) have relatively poor seed longevities, even under relatively good storage conditions, is confirmed by these data. Previous studies usually have been based upon storage at ambient conditions or under elevated temperatures and/or RH. Barton (1953) showed that carrot, onion, and pepper stored as well as eggplant and tomato when kept at $-4 \mathrm{C}$ 
for 20 years. After 50 to 60 years of storage under conditions described here, carrot, onion, and pepper are clearly less long-lived than okra or tomato.

Many vegetable species had seed longevities and predicted $\mathrm{P}_{50}$ of $>50$ years (Table 2). Okra, pea, and tomato seed in particular appear to have a potential longevity approaching that reported for some agronomic species such as barley (Hordeum vulgare L.), oats (Avena sativa L.) (123 years, Aufhammer and Simon, 1957), and red clover (Trifolium pratense L.) (100 years, Youngman, 1951). Had these seed lots been stored under conditions of subfreezing or cryogenic temperatures for the entire time, it is quite possible that they may have survived 60 years with a minimal loss of viability, such longterm storage being the ultimate objective of seed gene banks.

\section{Literature Cited}

Association of Official Seed Analysts. 1988. Rules for testing seeds. J. Seed Technol. 12(3):1-122.

Aufhammer, G. and U. Simon. 1957. Die Samen landwirtschaftlicher Kulterpflanzen im Grundstein des ehemaligen Nurnberger Stadttheaters und ihre Keimfahigkeit. Z. Acker Pflanzenbau 103:454-472.

Barton, L.V. 1953. Seed storage and viability. Contrib. Boyce Thompson Inst. 17(2):87-103.

Barton, L.V. 1961. Seed preservation and longevity. Interscience Pub., New York. p. 5054.

Bass, L.N. 1981. Storage conditions for maintaining seed quality, p. 239-321. In: E.E. Finney, Jr. (ed.). CRC handbook of transportation and marketing in agriculture, vol. 2. Field crops. CRC Press, Boca Raton, Fla.

Bass, L.N. 1983. Longevity of cantaloupe seeds. J. Seed Technol. 8(1):1-5.

Becquerel, M.P. 1934. La longevite des graines macrobiotiques. C.R. Acad. Sci. 199:16621664

Boswell, V.R., E.H. Toole, V.K. Toole, and D.F. Fisher. 1940. A study of rapid deterioration of vegetable seeds and methods for its prevention. U.S. Dept. Agr. Tech. Bul. 708.

Buchwald, N.F. and H.A. Jensen. 1974. Examination of the germination capacity of seeds from an approximately 60 years old seed collection. Kgl. Veterinaer-og Landbohojsk. Arsskr. (Denmark). p. 118-124.

Ellis, R.H. 1991. The longevity of seeds. HortScience 26:1119-1125.

Ellis, R.H., T.D. Hong, and E.H. Roberts. 1989. A comparison of the low moisture-content limit to the logarithmic relation between seed moisture and longevity in twelve species. Ann. Bot. 63:601-611.

Ellis, R.H., T.D. Hong, and E.H. Roberts. 1990a. Moisture content and longevity of seeds of Phaseolus vulgaris. Ann. Bot. 66:341-348.

Ellis, R.H., T.D. Hong, E.H. Roberts. and K.L. Tao. 1990b. Low moisture content limits to relations between seed longevity and moisture. Ann. Bot. 65:493-504.

Ellis, R.H. and E.H. Roberts. 1980. Improved equations for the prediction of seed longevity. Ann. Bot. 45:13-30.

Ewart, A.J. 1908. On the longevity of seeds. Proc. Royal Soc. Victoria 21:1-210.

Haferkamp, M.E., L. Smith, and R.A. Nilan. 1953. Studies on aged seeds. I. Relation of age of seed to germination and longevity. Agron. J. 45:434437.
James, E., L.N. Bass, and D.C. Clark. 1964 Longevity of vegetable seeds stored 15 to 30 years at Cheyenne, Wyoming. Proc. Amer. Soc. Hort. Sci. 84:527-534.

Justice, O.L. and L.N. Bass. 1978. Principles and practices of seed storage. U.S. Dept. Agr. Hdbk. 506. U.S. Govt. Printing Office, Washington, D.C.

Kivilaan, A. and R.S. Bandurski. 1981. The one hundred-year period for Dr. Beal's seed viability experiment. Amer. J. Bot. 68:1290-1292.

Lerman, J.C. and E.M. Cigliano. 1971. New carbon-14 evidence for 600 years old Canna compacta seed. Nature (London) 232:568-570.

Moore, F.D. and E.E. Roos. 1982. Determining differences in viability loss rates during seed storage. Seed Sci. Technol. 10:283-300.

Moore, F.D. III, A.E. McSay, and E.E. Roos. 1983. Probit analysis: A computer program for evaluation of seed germination and viability loss rate. Colorado Agr. Expt. Sta. Tech. Bul. 147.

Nabhan, G.P. 1977. Viable seeds from prehistoric caches? Archaeobotanical remains in Southwestern folklore. The Kiva 43:143-159.

Nature. 1942. Recent work on germination. Nature (London) 149:658-659.

Newhall, A.G. and J.K. Hoff. 1960. Viability and vigor of 22 year old onion seed. Seed World 86(12):4-5.

Odum, S. 1965. Germination of ancient seeds. Floristical observations and experiments with archaeologically dated soil samples. Dan. Bot. Arkiv 24(2):1-70.
Pack, D.A. and F.V. Gwen. 1950. Viability of sugar beet seed held in cold storage for 22 years. Proc. Amer. Soc. Sugar Beet Technol. 6:127129

Priestley, D.A. 1986. Seed aging: Implications for seed storage and persistence in the soil. Cornell Univ. Press, Ithaca, N.Y.

Priestley, D.A., V.I. Cullinan, and J. Wolfe. 1985. Differences in seed longevity at the species level. Plant Cell \& Environ. 8:557-562.

Roberts, E.H. 1972. Storage environment and the control of viability, p. 14-58. In: E.H. Roberts (ed.). Viability of seeds. Chapman and Hall, London.

Roberts, E.H. 1973. Predicting the storage life of seeds. Seed Sci. Technol. 1:499-514.

Roos, E.E. 1986. Precepts of successful seed storage, p. 1-25. In: M.B. McDonald, Jr. and C.J. Nelson (eds.). Physiology of seed deterioration. Spec. Pub. no. 11. Crop Sci. Soc. Amer., Madison, Wis.

Roos, E.E. 1989. Long-term seed storage. Plant Breeding Rev. 7:129-158.

Sivori , E., F. Nakayama, and E. Cigliano. 1968. Germination of Achira seed (Canna sp.) approximately 550 years old. Nature (London) 219:1269-1270.

Toole, V.K. 1986. Ancient seeds: Seed longevity. J. Seed Technol. 10(1):1-23.

Vertucci, C.W. and E.E. Roos. 1990. Theoretical basis of protocols for seed storage. Plant Physiol. 94:1019-1023.

Youngman, B.J. 1951. Germination of old seeds. Kew Bul. 6:423-426.

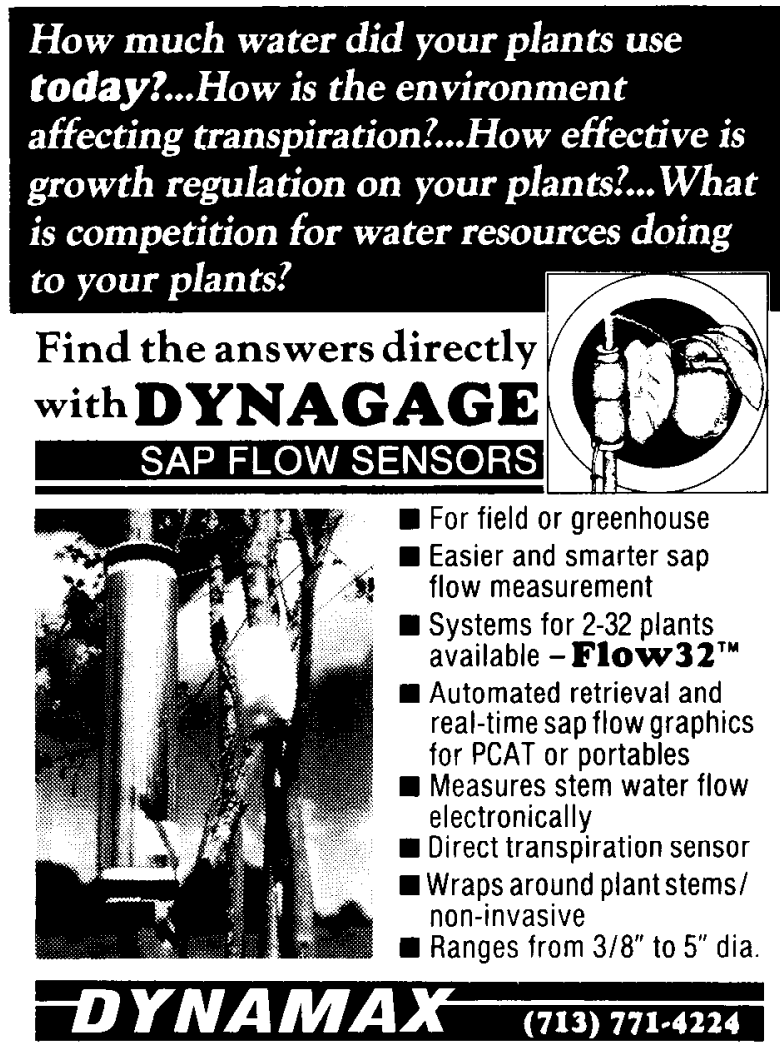

9888 Bissonnet, Suite 150 - Houston, TX 77036 - Fax: (713) 771-4102 